\title{
PERIKATAN BERSYARAT DAN BEBERAPA PERMASALAHANNYA
}

\author{
Herlien Budiono \\ email: adrinuha@bdg.centrin.net.id
}

\begin{abstract}
Unpredictability is a factor which has always to be dealt with when making contracts and is related to some act (juridical) which may or may not happen. This unpredictability may be the result of an act/commission or ommission to be perfomed by an unknown person, known person or a third person. In respons to this unpredicability, to a contract can be added a conditionality in which failure to meet certain conditions will result in postponement or cancellation. Conditionality may also be employed in making one sided juridical acts, such as a will or a power of attorney. A contract in which one or both parties is required to obtain prior consent before the contract can be performed is a conditional contract. A conditional contract differs from a contract with a time-limit and contract with an obligation. In addition, there are impossible condition, inevitable condition, unlawful condition, indecent condition, potestatif condition, and incomprehensible condition. In regard to a will, attention must be given to the difference between fideï-commis and contract with an obligation. A contract with the conditionality of annulment also differs from an obligation to stand for a surety. The law regulation in articles 1266 and 1267 KUHPerdata acknowledges the conditionality related to annulment which is always assumed in reciprocal contract.
\end{abstract}

Keywords:

contract, agreement, conditional, annulment, postponement, unpredictable

\begin{abstract}
Abstrak:
Ketidakpastian merupakan faktor yang harus diperhitungkan dalam pembuatan perikatan dan terkait dengan peristiwa yang akan terjadi dan yang masih belum tentu akan terjadi. Ketidakpastian dapat berada di tangan seseorang yang tidak ditentukan atau telah ditentukan orangnya atau ditentukan oleh pihak ketiga tertentu. Berhadapan dengan ketidakpastian, maka dikenal perikatan dengan syarat batal atau syarat tangguh. Keduanya dikaitkan dengan terjadi atau tidak terjadinya suatu peristiwa tertentu. Dengan adanya syarat menangguhkan berarti akibat hukum perikatan ditangguhkan. Syarat batal apabila dipenuhi menghentikan perikatan dan membawa segala sesuatu pada keadaan semula, seolah-oleh tidak pernah ada suatu perikatan. Selain diterapkannya syarat pada perikatan, syarat dapat pula diterapkan pada tindakan hukum sepihak seperti pada wasiat atau kuasa. Perikatan yang ternyata mensyaratkan diperolehnya oleh satu atau kedua pihak izin terlebih dahulu dari instansi pemerintah adalah perikatan bersyarat. Perikatan bersyarat harus dibedakan dari perjanjian memakai ketetapan waktu (tijdsbepaling), dan perikatan atas beban (last). Selain hal tersebut dikenal pula syarat yang tidak mungkin (onmogelijke voorwaarde), syarat yang perlu (noodzakelijk voorwaarde), syarat yang bertentangan dengan undang-undang (onwettige voorwaarde), syarat bertentangan dengan kesusilaan (onzedelijke voorwaarde), syarat potestatif dan syarat yang tidak dimengerti (onverstaanbare voorwaarde). Berkaitan dengan wasiat hendaknya diperhatikan adanya perbedaan antara pengangkatan waris dengan lompat tangan (fideï-commis) dan perikatan atas beban. Berbeda pula syarat batal dan janji menanggung atau menjamin (garansi). Ketentuan undang-undang mengenal di dalam Pasal 1266 dan 1267 KUHPerdata syarat batal yang selalu dicantumkan dalam perjanjian yang bertimbal balik.
\end{abstract}

Kata kunci:

perikatan, bersyarat, membatalkan, menangguhkan, tak terduga 


\section{Pengantar}

Tindakan atau perbuatan manusia ada yang berakibat hukum dan ada pula yang tidak berakibat hukum. Akibat hukum itu terjadi karena ada pernyataan kehendak orang yang ditujukan untuk terjadinya akibat hukum yang dinamakan tindakan hukum atau perbuatan hukum. Tindakan hukum dapat berupa tindakan hukum sepihak yang merupakan tindakan yang dilakukan oleh satu pihak saja yang menimbulkan, berubah, dan berakhirnya suatu hak seperti pada pembuatan surat wasiat, penolakan atas harta peninggalan atau pengakuan anak. Perjanjian merupakan tindakan hukum berganda yang memerlukan kerja sama dari dua pihak atau lebih untuk memunculkan akibat hukum. ${ }^{1}$ Tanpa adanya penjelasan lebih lanjut mengenai perjanjian menunjuk pada perjanjian obligatoir yakni perjanjian yang menimbulkan perikatan.

Tidak semua perikatan yang timbul karena perjanjian ditutup dan segera berakhir sebagaimana diharapkan oleh para pihak. Ada kalanya perjanjian dilakukan dengan dikaitkan pada syarat yang dapat berupa syarat menangguhkan (opschortende voorwaarde) atau syarat membatalkan (ontbindende voorwaarde).

Pasal 1253 Kitab Undang-Undang Hukum Perdata (KUHPerdata):

"Suatu perikatan adalah bersyarat manakala ia digantungkan pada suatu peristiwa yang masih akan datang dan yang masih belum tentu akan terjadi, baik secara menangguhkan perikatan hingga terjadinya peristiwa semacam itu, maupun secara membatalkan perikatan menurut terjadi atau tidak terjadinya peristiwa tersebut."

Dengan mencantumkan syarat di dalam perikatan baik syarat membatalkan ataupun syarat menangguhkan akan membawa akibat hukum yang berbeda terhadap perikatan tersebut.

\section{Apa Yang Dimaksud Dengan Syarat}

Di dalam KUHPerdata, ketentuan mengenai syarat tidak diatur di bagian perjanjian tetapi di bagian perikatan, yakni pasal-pasal 1253-1267 KUHPerdata.

1 Herlien Budiono, Ajaran Umum Hukum Perjanjian dan Penerapannya di Bidang Kenotariatan, PT. Citra Aditya Bakti, Bandung, 2014, hlm., 1-13. 
Pengertian kata "syarat" diterapkan dalam kaitannya dengan syarat menangguhkan (opschortende voorwaarde) dan syarat membatalkan (ontbindende voorwaarde) dan menunjuk selalu pada tujuan untuk timbulnya atau berlangsungnya suatu peristiwa hukum yang bergantung pada peristiwa yang belum tentu terjadi atau tak terduga. Pada umumnya ketentuan mengenai syarat baik syarat menangguhkan maupun syarat membatalkan adalah dalam hubungannya dengan perikatan yang timbul karena perjanjian.

Syarat merupakan bagian khusus yang dapat dikatakan sebagai bagian accidentalia dari perjanjiannya sendiri. Sebenarnya bukan perbuatan hukumnya yang bersyarat tetapi akibat hukumnya. Perbuatan hukumnya sendiri tidak bersyarat, tetapi dengan adanya syarat yang dijanjikan berakibat ditundanya akibat hukum setelah dipenuhi syarat tersebut.

Pasal 6:21 Nieuw Burgerlijk Wetboek (NBW)2 lebih sederhana mengatur mengenai syarat dengan menyebutkan bahwa perikatan adalah bersyarat apabila akibat hukum dari perbuatan hukumnya digantungkan pada kejadian yang belum tentu.

Walaupun oleh para pihak telah tidak ditentukan suatu syarat akan tetapi bila akan diterapkan ketentuan perikatan bersyarat, misalnya di dalam suatu perikatan ternyata diharuskan adanya izin terlebih dahulu dari instansi pemerintah, sedangkan untuk dikeluarkannya izin harus dipenuhi pula peraturan tertentu. Pada perikatan tersebut di mana diperoleh atau tidaknya izin mengakibatkan timbulnya suatu periode yang tidak menentu akan dipenuhinya syarat berupa izin merupakan elemen dari perikatan bersyarat dan memberi dampak serta menentukan perikatan tersebut. Syarat tersebut walaupun ditimbulkan bukan oleh para pihak tetapi ditentukan peraturan tertentu, menyebabkan secara analogi diterapkan Pasal 1253 KUHPerdata pada perikatan tersebut, demikian Houwing. ${ }^{3}$

\footnotetext{
2 "Een verbintenis is voorwaardelijk, wanneer bij rechtshandeling haar werking van een toekomstige onzekere gebeurtenis afhankelijk is gesteld".

$3 \mathrm{Ph}$. A. N. Houwing, Verboden overeenkomsten, WPNR 4069.
} 
Selain diterapkannya syarat pada perikatan, Asser-Rutten ${ }^{4}$ berpendapat bahwa Pasal 1253 KUHPerdata dapat diterapkan di luar perikatan yakni dicantumkan pada tindakan hukum sepihak seperti pada wasiat atau kuasa (volmacht).

\section{Peristiwa Yang Akan Terjadi Dan Yang Masih Belum Tentu Akan Terjadi}

Mengingat pada sifat terbuka dari perjanjian serta asas kebebasan berkontrak, berarti bahwa di dalam perjanjian oleh para pihak dapat diperjanjikan suatu syarat sepanjang syarat tersebut tidak bertentangan dengan undangundang, ketertiban umum atau kesusilaan.

Tujuan dari suatu syarat adalah menentukan adanya atau keberadaan suatu hubungan hukum yang digantungkan pada ada atau tidaknya peristiwa yang akan terjadi dan yang masih belum tentu akan terjadi. Hal tersebut essensial pada semua syarat yang dijanjikan. Peristiwa yang belum tentu memberi efek atau akibat praktis yang penting, lagipula adanya faktor ketidakpastian yang secara teoretis harus diketahui untuk membedakan perikatan bersyarat dengan perjanjian memakai ketetapan waktu (tijdsbepaling). Ketidakpastian merupakan faktor yang harus ada sebagai peristiwa yang akan terjadi dan yang masih belum tentu akan terjadi. Janji yang dikaitkan pada ketetapan waktu (tijdsbepaling) tidak menangguhkan perikatan melainkan hanya menangguhkan pelaksanaannya saja (Pasal 1268 KUHPerdata), misalnya meninggalnya seseorang atau tercapainya umur tertentu merupakan peristiwa yang pasti akan terjadi. Pengertian "tidak pasti" mengandung muatan yang dapat berbeda tergantung pada apa yang dimaksudkan oleh para pihak dengan suatu peristiwa yang belum tentu akan terjadi atau sebagai peristiwa yang mungkin terjadi atau suatu keadaan bahwa suatu peristiwa pasti akan terjadi.

Apa yang dimaksudkan oleh para pihak bahwa fakta yang akan terjadi sebagai ketidakpastian ataukah yang dimaksudkan adalah ketidakpastian sebagai sesuatu yang pasti? Contoh: A menghibahkan rumahnya kepada B dengan syarat

\footnotetext{
${ }^{4}$ Asser-Rutten, De verbintenis in het algemeen, deel I, Zwolle, 1981, hlm., 124-125.
} 
bahwa B boleh menghuni rumah tersebut apabila A mencapai umur 65 (enam puluh lima) tahun. Apakah telah terjadi perikatan dengan syarat menangguhkan atau perikatan dengan ketetapan waktu (tijdsbepaling)? Apabila A meninggal dunia sebelum mencapai umur 65 (enam puluh lima) tahun apakah B boleh atau tidak menghuni rumah tersebut? Adakah di sini suatu fakta yang tidak pasti diartikan sebagai kepastian? Hanya para pihaklah yang mengetahui apa yang dimaksudkan dengan mencapai umur 65 (enam puluh lima) tahun sebagai "ketidakpastian" atau sebagai "ketetapan waktu (tijdsbepaling)".

Apabila maksud para pihak bahwa perikatan harus dilaksanakan dengan terjadinya peristiwa yang belum tentu, yakni A mencapai umur 65 (enam puluh lima) tahun, maka sebenarnya keraguan apakah kita berhadapan dengan perikatan bersyarat menjadi hilang, dan dalam hal ini kita berhadapan dengan perikatan memakai ketetapan waktu (tijdsbepaling).

Jika peristiwa yang belum tentu ternyata tidak terjadi karena A meninggal sebelum berumur 65 (enam puluh lima) tahun, sedangkan tujuan atau maksud para pihak sudah pasti, yakni penghibahan maka penghibahan harus dilaksanakan. Dalam hal ini, itikad baik akan menjadi arahan dan pelaksanaan perikatan harus dilaksanakan "seandainya" A mencapai umur 65 (enam puluh lima) tahun.

Untuk menentukan apakah para pihak sadar atau tidak sadar akan fakta/peristiwa yang mungkin terjadi, maka fakta obyektiflah yang menentukan. Ketidakpastian dapat ditentukan, yakni: ${ }^{5}$

a. Ketidakpastian yang akan terjadi dapat berada di tangan seseorang yang tidak ditentukan siapa orangnya. Misalnya, kewajiban membayar penggantian kerugian kepada pihak yang diasuransikan oleh pihak perusahaan asuransi ditangguhkan hingga terjadinya kerugian yang ditimbulkan seseorang (yang tidak ditentukan siapa orangnya);

5 J.D.A. den Tonkelaar, Opschortende en ontbindende voorwaarden volgens $B W$ en $N B W$, Tjeenk Willink, Zwolle, 1983, hlm., 20. 
b. Ketidakpastian yang akan terjadi telah ditentukan orangnya, seperti dalam hal suatu hibah wasiat (legaat) dengan syarat (menangguhkan) apabila A menjadi mahasiswa fakultas hukum;

c. Ketidakpastian yang akan terjadi ditentukan pada terjadinya peristiwa oleh pihak ketiga tertentu. Misalnya, perjanjian jual beli persil dengan syarat (menangguhkan) setelah diperolehnya izin bangunan atau setelah calon pembeli memperoleh kredit dari bank.

Pemenuhan suatu syarat yang semata-mata tergantung pada salah satu pihak dikenal sebagai perikatan dengan syarat potestatif, yakni syarat yang tergantung kepada kehendak salah satu pihak saja. Pasal 1260 KUHPerdata6 secara tidak langsung membenarkan adanya perikatan dengan syarat potestatif.

Untuk jelasnya, suatu arest yang terjadi di Pengadilan Negeri Amsterdam (16 Nopember 1928, NJ 1929, p 1142) berkaitan dengan ketentuan pasal 1260 KUHPerdata (pasal 1296 BW lama). Perjanjian antara Biro Advertensi Pusat (Centraal Advertentie Bureau) dengan penerbit Berita Olahraga (Sportkroniek) dengan syarat bahwa majalah tersebut akan memasang iklan untuk General Motor dengan ketentuan menggunakan fasilitas sebanyak 10.000 (sepuluh ribu) baris per tahun. Ternyata General Motor mengirim bahan yang tidak cukup untuk pemasangan iklan yang dijanjikan walaupun majalah tersebut telah menegur mengenai kekurangan bahan iklannya. Akibatnya majalah terbit dengan 16 (enam belas) halaman kosong yang disediakan untuk iklan General Motor. Penerbit tetap menagih pembayaran termasuk halaman-halaman kosong karena telah disediakan untuk iklan General Motor. Dengan tidak dilakukan pemasangan iklan per tahun yang telah dijanjikan berarti pihak General Motor telah tidak beritikad baik untuk melaksanakan perjanjian tersebut dan hakim berpendapat, bahwa General Motor telah "menghalang-halangi terpenuhinya syarat dan syarat dianggap telah

\footnotetext{
6 Pasal 1260 KUHPerdata: "Syarat dianggap telah terpenuhi, jika si berutang yang terikat olehnya, telah menghalang-halangi terpenuhinya syarat itu".
} 
terpenuhi" sebagaimana dimaksudkan Pasal 1260 KUHPerdata (Pasal 1296 BW lama) dan General Motor wajib membayar kepada penerbit. ${ }^{7}$

\section{Syarat Yang Tidak Sungguh-Sungguh}

Hal esensial pada perikatan bersyarat adalah kejadian yang akan datang dan belum tentu terjadi. Walaupun para pihak dapat mempengaruhi dan beranggapan telah menentukan mengenai ketidakpastian yang mereka maksudkan, tetapi ketentuan utama adalah suatu ketidakpastian obyektif. Apabila telah diformalisasikan suatu syarat untuk suatu waktu tertentu tetapi ketidakpastian ternyata tidak terjadi di masa waktu tersebut, maka menurut hukum tidak dapat dikatakan adanya perikatan bersyarat (pasal 1258, ayat 1, KUHPerdata). Dalam hal ini telah terjadi perikatan tanpa syarat; yakni adanya "syarat yang tidak sungguh-sungguh" sehingga telah terjadi perikatan tanpa syarat yang oleh para pihak dilihat atau dianggap sebagai syarat.

Jikalau tidak ditentukan kapan syarat harus dipenuhi, maka syarat tersebut setiap waktu dapat dipenuhi, dan syarat itu tidak dianggap tidak ada sebelum ada kepastian bahwa peristiwa tidak akan terjadi (pasal 1258, ayat 2, KUHPerdata). Ketidakpastian akan gugur apabila kejadian tidak lagi merupakan peristiwa yang akan datang, tetapi peristiwa telah terjadi pada saat syarat ditentukan atau peristiwa tersebut di masa yang akan datang tidak akan terjadi.

Bedakan dengan syarat yang tidak mungkin dilaksanakan (onmogelijke voorwaarde) seperti "apabila anjing saya minum air laut sampai habis"; suatu syarat yang tidak perlu dipermasalahkan mengenai aspek akan datang karena peristiwa tersebut tidak mungkin akan terjadi.

\section{Syarat Positif Dan Syarat Negatif}

Dari formulasi perikatan bersyarat menunjukkan perbedaan adanya sifat syarat positif dan sifat syarat negatif. ${ }^{8}$ Perbedaan tersebut sederhana, yakni:

\footnotetext{
${ }^{7}$ Supra no 5, hlm., 22.

8 Id., hlm., 24.
} 
a. Syarat postitif, dengan terjadinya suatu kejadian akan membawa akibat;

b. Syarat negatif, dengan tidak terjadinya suatu kejadian diartikan adanya kenyataan yang membawa efek.

Perbedaan kedua sifat tersebut menjadi tidak berarti karena seiring syarat membatalkan yang negatif dapat tercapai juga dengan syarat menangguhkan positif. Hal tersebut tergantung pada formulasi dan maksud para pihak di dalam menyatakan syarat yang dimaksud di dalam perjanjian.

Misalnya, pada jual beli antara A sebagai penjual dan B sebagai pembeli dengan syarat diperolehnya izin usaha atas nama B dari instansi yang berwenang.

a. Syarat negatif membatalkan: apabila izin usaha atas nama B tidak diperoleh maka perjanjian jual beli batal.

b. Syarat positif menangguhkan: A menjual kepada B apabila izin usaha telah diperoleh atas nama B.

Pitlo-Van der Burght ${ }^{9}$ memberi contoh suatu syarat di mana dasar dari tujuan pewaris mencantumkan syarat negatif menangguhkan harus dibaca sebagai syarat positif membatalkan. Pewaris memberikan hibah wasiat (legaat) kepada A dengan syarat (menangguhkan) bahwa A tidak dan tidak akan bertempat tinggal di luar negeri. Apabila A hendak menikmati legaat tersebut, maka syarat tersebut harus dibaca sebagai A mendapat hibah wasiat (legaat) dengan syarat positif membatalkan, asalkan ia bertempat tinggal di dalam negeri. Hibah wasiat (legaat) diperoleh A akan tetapi apabila A bertempat tinggal di luar negeri maka hibah wasiat (legaat) tersebut menjadi batal.

\section{Syarat Menangguhkan Dan Syarat Membatalkan}

Suatu perikatan adalah bersyarat manakala perikatan digantungkan pada suatu peristiwa yang masih akan datang dan yang masih belum tentu akan terjadi, baik secara menangguhkan perikatan hingga terjadinya peristiwa semacam itu, maupun secara membatalkan perikatan menurut terjadi atau tidak terjadinya peristiwa tersebut (pasal 1253, KUHPerdata).

\footnotetext{
9 A. Pitlo, bewerkt door Gr. van der Burght, Het Erfrecht, deel 5, Arnhem, 1977, hlm., 66.
} 
Dengan adanya syarat menangguhkan berarti akibat hukum perikatan ditangguhkan sedangkan dengan dipenuhi syarat, maka perikatan menjadi batal pada syarat membatalkan, demikian Opzomer. ${ }^{10}$ Lain halnya dengan pendapat Diephuis ${ }^{11}$ yang mengatakan bahwa yang menjadi dasar dari syarat membatalkan dan menangguhkan adalah maksud tujuan dari para pihak di mana suatu tindakan hukum ditujukan untuk timbulnya akibat hukum dan bukannya tidak atau hilangnya akibat hukum.

\section{a) Syarat menangguhkan}

Perikatan dengan syarat tangguh bergantung pada peristiwa yang masih akan datang dan yang masih belum tentu akan terjadi; perikatan tidak dapat dilaksanakan sebelum peristiwanya telah terjadi. Pada perikatan dengan syarat tangguh berarti bahwa barang yang menjadi pokok perikatan tetap menjadi tanggungan debitur, yang wajib menyerahkan barang tersebut apabila syarat dipenuhi. Adapun jika kreditur meninggal dunia sebelum dipenuhinya syarat, maka hak-haknya beralih kepada ahli warisnya (pasal 1261, ayat 2, KUHPerdata).

Apabila ternyata syarat telah terpenuhi, maka syarat itu berlaku surut hingga saat lahirnya perikatan (pasal 1261, ayat 1, KUHPerdata), demikian pula syarat telah dipenuhi tetapi tidak diketahui oleh para pihak maka perikatan mulai berlaku sejak hari perikatan dilahirkan (pasal 1263, ayat 1, KUHPerdata).

Syarat tangguh menangguhkan tidak saja akibat hukumnya tetapi sebetulnya adalah alas hak mengalihkan yang ditangguhkan. Pada asasnya perbuatan hukumnya telah terjadi dan tidak bersyarat walaupun perikatannya bersyarat dalam artian bahwa akibat hukum dari perikatan tersebut yakni peralihan haknya/prestasinya ditangguhkan.

A menghibahkan sebuah mobil kepada B apabila B lulus S1. Apabila ternyata A telah menyerahkan mobil (bergerak berwujud) kepada B sedangkan syarat apabila B lulus S1 belum dipenuhi. B adalah pemegang kedudukan

${ }^{10}$ C.W. Opzomer, Het Burgerlijk Wetboek verklaard, vijde deel, Amsterdan, 1879, hlm., 123-124.

11 G. Diephuis, Het Nederlandsch Burgerlijk regt, Groningen, 1886, hlm., 106. 
berkuasa (bezitter) dan akan menjadi pemilik mobil tersebut dengan dipenuhinya syarat tangguh (lulus S1). Dengan kata lain, A masih berhak atas mobil tersebut walaupun mobil tersebut telah dipegang B. Apabila ternyata di kemudian hari dipenuhi syarat tangguhnya (B lulus S1), maka B menjadi pemilik atas mobil sedangkan A (ex pemilik) telah selesai di dalam melaksanakan prestasi dan tidak diperlukan adanya penyerahan khusus atas mobil yang dijanjikan antara A-B.

Perbedaan akan terlihat berkaitan dengan jenis benda yang diperjanjikan. Berkaitan dengan penyerahan atas benda bergerak tidak terdaftar (terregistrasi) seperti pada sewa-beli, penjual/yang menyewakan setelah menyerahkan bendanya kepada pembeli/penyewa, maka kedudukan penjual/yang menyewakan tetap sebagai pemilik sedangkan pada saat yang sama pembeli/penyewa menjadi pemegang (detentor) sekaligus pemilik dengan syarat tangguh.

Berkaitan dengan benda tetap atau benda terregistrasi (misalnya tanah hak milik), maka pelaksanaan/akibat hukumnya dilakukan dengan menunggu terjadinya atau dipenuhinya syarat yang dijanjikan. Sulit untuk melaksanakan penyerahan benda tetap tersebut dan mendaftarkan/balik nama bendanya dengan mencantumkan syarat tangguh lagipula peralihan hak tersebut berakibat hukum terhadap pihak ketiga.

Di dalam praktik, dikenal perjanjian pengikatan jual beli (PPJB) atas persil yang dapat digolongkan pada perikatan dengan syarat menangguhkan. PPJB merupakan perjanjian obligatoir berfungsi sebagai perjanjian bantuan guna mempersiapkan untuk nantinya membuat perjanjian pokok yakni perjanjian jual beli (perjanjian kebendaan). Dilakukannya PPJB biasanya karena belum dapat dipenuhinya syarat untuk dilakukannya jual beli di hadapan pejabat pembuat akta tanah seperti belum lunasnya harga jual beli. ${ }^{12}$

Terhadap benda bergerak tidak berwujud, cessie atas hak tagih, maka hak tagih telah beralih sejak akta cessie ditandatangani oleh cedent dan cessionaris. Pemberitahuan (betekening) kepada debitur-cessus merupakan suatu keharusan

\footnotetext{
12 Supra no 1, hlm., 64-65.
} 
untuk dilakukan agar debitur-cessus mengetahui kepada siapa debitur-cessus harus membayar utangnya. Oleh karena itu dalam hal dibuatnya cessie dengan syarat tangguh, perlu untuk mencantumkan syarat tangguh tersebut di dalam akta cessie sehingga dengan dipenuhi syarat yang dijanjikan berakibat bahwa cessionaris berhak atas hak tagih piutang yang diperoleh dari cedent dan pembayarannya dari debitur-cessus. ${ }^{13}$

Singkat kata, selama syarat tidak atau belum dipenuhi, maka pihak yang menyerahkan tetap berwenang atas bendanya tetapi dengan dibebani kewajiban penyerahan yang ditangguhkan. Di lain pihak, pihak yang memperoleh bendanya menjadi berwenang tetapi semata-mata dengan posisi hak kepemilikan atas bendanya yang ditangguhkan.

\section{b) Syarat membatalkan}

Syarat batal apabila dipenuhi menghentikan perikatan, dan membawa segala sesuatu kembali pada keadaan semula, seolah-olah tidak pernah ada suatu perikatan (ex tunc-pasal 1265, ayat 1, KUHPerdata). Syarat batal tidak menangguhkan pemenuhan perikatan, tetapi mewajibkan kreditur mengembalikan apa yang telah diterimanya, apabila peristiwa yang dimaksudkan terjadi (pasal 1265, ayat 2, KUHPerdata).

Pada penunjukkan waris (making) bersyarat tergantung pada syarat tangguh atau syarat membatalkan sehingga ada kemungkinan bahwa pada saatnya making harus direalisasikan (syarat tangguh) atau mengakhiri making yang diberikan oleh pewaris (syarat batal). Pada penunjukkan waris dengan syarat menangguhkan menimbulkan ketidakpastian dilaksanakannya making tersebut selama syarat belum dipenuhi atau pemenuhan syarat tidak mungkin dilaksanakan. Selama itu ahli waris memegang apa yang menjadi warisan yang diperuntukkan kepadanya. Pada penunjukkan waris dengan syarat membatalkan maka making dilaksanakan tetapi dengan dipenuhinya syarat (batal) berakibat apa yang diperuntukkan padanya harus dikembalikan.

${ }^{13}$ Id. hlm., 185-196. 
Di dalam formulasi perjanjian hendaknya dibedakan apakah merupakan syarat membatalkan atau justru merupakan pokok perjanjian. Misalnya, perjanjian pemborongan bangunan dengan izin membangun yang dikeluarkan pemerintah kepada pemborong dengan beding, bahwa pembangunan gedung harus selesai dalam waktu 2 (dua) tahun dan akan dikenakan denda apabila tidak selesai. Pemborong ternyata tidak dapat menyelesaikan pembangunan sesuai jadwal yang ditentukan (dua tahun). Hof Amsterdam (26 juni 1946, NJ 1947, 7)14 memutuskan, bahwa kewajiban membangun dalam waktu 2 (dua) tahun, bukan merupakan syarat tetapi justru merupakan pokok perjanjian.

Hal yang sama telah diputuskan sebelumnya oleh Hof Amsterdam (12 Januari 1944, NJ 1944/1945, 296) ${ }^{15}$, di mana pada jual beli telah diperjanjikan bahwa sisa harga jual beli akan dibayar dalam waktu 4 (empat) hari yang oleh pengadilan dianggap sebagai pokok perjanjian dan bukan syarat.

\section{Perikatan Bersyarat, Perikatan Dengan Ketetapan Waktu (Tijdsbepaling) Atau Termin (Termijn)}

Apabila di dalam suatu perikatan tidak ditentukan kapan harus dilaksanakan prestasinya, maka debitur dapat segera memenuhi prestasi tersebut sedangkan kreditur dapat minta agar debitur segera memenuhi prestasi yang telah dijanjikannya. "Segera" tidak dimaksudkan secara harfiah "saat itu juga" tetapi menurut ukuran kepantasan dan kepatutan. Apabila tidak demikian halnya, maka debitur akan dalam waktu relatif cepat dapat dinyatakan telah lalai. Ketidakpastian tersebut dapat dihindari dengan janji ketetapan waktu (tijdsbepaling). Ketetapan waktu tidak menangguhkan perikatan, melainkan hanya menangguhkan pelaksanaannya (pasal 1268, KUHPerdata) dan memberi kepastian kepada pihak kreditur bahwa prestasi pasti akan dilakukan pada waktu

\footnotetext{
14 Supra no 5, hlm., 27.

15 Dikutip dari J.D.A. den Tonkelaar, Opschortende en ontbindende voorwaarden volgens BW en NBW, Tjeenk Willink, Zwolle, 1983, hlm., 27; C. Asser-L.E.H. Rutten, De verbintenis in het algemeen, I, Zwolle, 1981, hlm., 115 dst; Jac.Hijma en M.M.Othof, Compendium van het Nederlands Vermogensrecht NBW, Tjeenk-Willink, Deventer, 1982, nrs. 40, hlm., 305 dan 345.
} 
yang telah dijanjikan. ${ }^{16}$ Dengan ketetapan waktu dimaksudkan agar peristiwa hukum pasti akan terjadi.

Lain halnya dengan perikatan bersyarat yang berarti para pihak bermaksud agar tindakan hukum baru berakibat hukum dengan terjadinya suatu peristiwa yang belum tentu atau dengan terjadinya peristiwa mengakibatkan hilangnya efek terhadap tindakan hukum tersebut.

Perbedaan utama antara perikatan bersyarat dan ketetapan waktu adalah akibat hukum yang digantungkan pada kepastian dan ketidakpastian peristiwa yang akan terjadi. Pada perikatan bersyarat, tidak ditentukan waktu pelaksanaan prestasi yakni boleh dilakukan atau akan dilakukan sehingga kreditur tidak dapat menuntut debitur untuk melaksanakan prestasi tersebut. Pada perikatan dengan ketetapan waktu, justru peristiwa dikemudian hari harus terjadi, hanya tinggal menunggu waktu saja.

Ketetapan waktu tidak dimaksudkan sebagai syarat menangguhkan, mengingat peristiwa dikemudian hari yang merupakan waktu dapat dituntutnya prestasi bagi kreditur merupakan sesuatu yang pasti. Justru pada perikatan dengan syarat menangguhkan, terjadinya peristiwa tidak dapat dituntut atau dipaksakan.

Ketetapan waktu ${ }^{17}$ dapat pula dimaksudkan sebagai saat tertentu (tijdstip) atau suatu masa (tijdvak). Saat tertentu (tijdstip) di mana prestasi dapat dituntut, seperti pembayaran selambat-lambatnya pada tanggal 5 Agustus 2015. Penentuan masa (tijdvak), misalnya penyewa diperbolehkan menikmati rumah dari tanggal 1 Mei 2014 hingga 1 Mei 2015. Ketetapan waktu dapat pula dalam artian jangka waktu atau masa dilakukannya prestasi, yakni di dalam jangka waktu mana debitur dapat memenuhi prestasinya, misalnya buruh yang harus menyelesaikan pembuatan tembok dalam jangka waktu 1 bulan. Penentuan masa (tijdvak) dapat dilakukan dengan dua cara:

\footnotetext{
16 L.C. Hofmann-S.N. van Opstall, Het Nederlands verbintenissenrecht, deel 1, negende druk, TjeenkWillink, Groningen, 1976, hlm., 406-407.

17 Id., hlm., 407-409.
} 
a. ditentukannya dua saat (tertentu) yang berbeda, saat dimulainya dan berakhirnya masa tersebut, misalnya dari tanggal 5 Agustus 2015 dan berakhir pada tanggal 5 Agustus 2016;

b. ditentukan suatu masa (tijdvak), misalnya selama bulan Agustus 2015 .

Berkaitan dengan penentuan masa dikenal istilah "termin" (jangka waktu, termijn $)^{18}$, yang diartikan sebagai masa (tijdvak) seperti pada sewa menyewa yang dilakukan untuk selama 3 (tiga) tahun, terhitung sejak tanggal 5 Agustus 2015.

Berakhirnya termin untuk suatu prestasi yang dilaksanakan secara berkelanjutan (terus menerus) seperti pada sewa menyewa tidak diartikan sebagai syarat membatalkan yang mengakibatkan perikatan menjadi berakhir. Penentuan termin tersebut tidak lain adalah menentukan batas (waktu) kewajiban prestasi dari pihak pemilik dan hak atas prestasi pada pihak penyewa. Apabila selama masa atau jangka waktu yang ditentukan penyewa telah menikmati masa sewa sebagaimana mestinya, maka perjanjian sewa-menyewa hapus karena pembayaran dalam arti umum yakni telah dipenuhinya prestasi oleh pihak pemilik (pasal 1381, KUHPerdata) dan berakhirnya penentuan masa (tijdvak) tetapi bukan putusnya perikatan karena dipenuhi syarat batal.

Apabila selama masa sewa-menyewa ternyata penyewa terganggu hak kenikmatannya yang berarti telah tidak dipenuhi prestasi sebagaimana mestinya, maka dalam hal ini terjadi wanprestasi pada pihak pemilik dan kemungkinan timbulnya perikatan untuk ganti rugi walaupun masa sewa telah berakhir.

"Termin" kadangkala juga dimaksudkan atau diformulasikan sebagai jangka waktu di mana debitur di dalam masa (tijdvak) yang ditentukan bisa menangguhkan prestasinya atau kadangkala dalam artian belum boleh melakukan prestasinya, misalnya pembayaran dilakukan dalam waktu 20 (dua puluh) hari atau penyerahan dilakukan setelah 2 (dua) bulan. Penentuan saat tertentu (tijdstip) diartikan sebagai masa tertentu (tijdstip) berakhir, yakni tanggal atau saat prestasi dapat ditagih oleh kreditur atau tanggal jatuh tempo pada utang.

18 Termijn=jangka waktu, termin, Kamus bahasa Belanda-Indonesia, Susi Moeimam, Hein Steinhaur, PT Gramedia Pustaka Utama, Jakarta, 2005, hlm., 1013. 
Penentuan saat tertentu (tijdstip) untuk perikatan tertentu berakibat, bahwa dengan tidak/terlambat dilakukannya prestasi menyebabkan tanpa adanya teguran (aanmaning) debitur telah melakukan wanprestasi, misalnya pesan taksi pada hari dan jam tertentu atau pesan baju pengantin untuk pernikahan pada hari tertentu.

Walaupun perbedaan antara saat tertentu (tijdstip) dan suatu masa (tijdvak) kelihatannya jelas, namun ada kalanya tidak demikian halnya di dalam praktik. Hal ini disebabkan karena kejelasan atau ketidakjelasan berkaitan dengan apa yang dianggap dan dilihat sebagai ketidakpastian. Apabila perbuatan hukum digantungkan pada "mencapai dewasanya A" atau "meninggalnya B", apakah memang para pihak bermaksud apabila A menjadi dewasa sebagai hal yang tidak pasti dan meninggalnya B sebagai peristiwa yang pasti akan terjadi atau para pihak sebenarnya telah mengetahui apa yang dimaksudkan dengan pasti dan tidak pasti tetapi para pihak mempunyai maksud tertentu di dalam menerapkan syarat atau termin. Menurut bunyi ketentuan Pasal 1263 KUHPerdata, maksud para pihak dan ketidakpastian obyektif yang menentukan dan dapat diterima atau dianggap oleh para pihak sebagai tidak pasti sebagai syarat agar berakibat hukum.

Dimungkinan untuk menetapkan kombinasi antara syarat dan penentuan suatu masa (tijdvak) sebagai satu beding, misalnya "pembayaran berkala selama 1 (satu) tahun (suatu masa, tijdvak) yang dilakukan dengan angsuran bulanan yang sama besarnya masing-masing angsuran sebesar Rp. (...) (syarat)".

\section{Perikatan Bersyarat, Pengangkatan Waris Dengan Lompat Tangan (Fideï- commis) Dan Perikatan Atas Beban (Last).}

Pada dasarnya suatu pengangkatan waris (making) dengan lompat tangan (fideï-commis) adalah penentuan dua kali oleh pewaris terhadap harta peninggalannya, yakni dua atau lebih ahli waris secara berturut-turut memperoleh hak warisnya dari pewaris yang sama. Penentuan ahli waris di dalam wasiat terhadap harta peninggalan oleh pewaris berdasar pengangkatan waris atau legataris dengan ketentuan masing-masing diwajibkan menyimpan barang 
warisan atau benda hibah wasiat untuk kemudian apabila ahli waris/legataris meninggal dunia menyerahkan barang warisan/benda hibah wasiat baik seluruhnya atau untuk sebagian kepada ahli waris lain yang ditunjuk pula oleh pewaris. Pengangkatan waris (making) dengan lompat tangan (fideï-commis) di muat di dalam pasal 879-881 KUHPerdata, dan pasal 973- 991 KUHPerdata.

Untuk jelasnya, oleh pewaris Nyonya A telah ditentukan dalam wasiatnya berupa pembentukan dana keluarga dengan perintah kepada pengurus harta peninggalan (bewindvoerder) untuk membayar nafkah (alimentasi) kepada suami pewaris (Tuan B) selama hidupnya dan setelah meninggalnya Tuan B tersebut, membayar alimentasi kepada anak-anak Ny A dan Tuan B. ${ }^{19}$ Contoh lain, yayasan yang didirikan oleh pewaris dengan surat wasiat dan sekaligus menunjuk yayasan sebagai ahli waris pertama, dan membayarkan secara berkala kepada anak-anak serta pembantu rumah tangga pewaris dan setelah meninggalnya anak-anak tersebut agar yayasan dilikuidasi dan harta peninggalan dibagikan kepada keturunan dari anak-anak tersebut. ${ }^{20}$

Pengangkatan waris atau pemberian hibah wasiat dengan lompat tangan (fideï-commis) adalah terlarang yang berakibat batal (pasal 879, ayat 1, KUHPerdata). ${ }^{21}$

Penentuan syarat membatalkan di dalam suatu wasiat dapat memuat penentuan atau penunjukan dua orang ahli waris berturut-turut terhadap harta peninggalan yang sama, penentuan syarat batal tersebut mirip dengan pengangkatan waris (making) dengan lompat tangan (fidë̈-commis).

Pada fidë̈-commis ada dua orang ahli waris berturut-turut yang ditentukan oleh pewaris, A diangkat sebagai ahli waris dan setelah A meninggal pewaris menunjuk dan mengangkat B sebagai ahli warisnya.

19 Hof Amsterdan 11 Februari 1948, NJ 1948, 313, dikutip dari J.D.A. den Tonkelaar, Opschortende en ontbindende voorwaarden volgens BW en NBW, Tjeenk Willink, Zwolle, 1983, hlm., 34.

20 Hof Amsterdam 14 Juni 1951, NJ 1951, 699, dikutip dari J.D.A. den Tonkelaar, Opschortende en ontbindende voorwaarden volgens BW en NBW, Tjeenk Willink, Zwolle, 1983, hlm., 34.

21 Pasal 879, ayat 1, KUHPerdata: "Pengangkatan waris atau pemberian hibah wasiat dengan lompat tangan, atau sebagai fidei-commis adalah terlarang". 
Pada making bersyarat, pewaris mengangkat A dengan syarat (membatalkan) apabila A hidup lebih lama daripada B dan B diangkat sebagai ahli waris dengan syarat (membatalkan) apabila B hidup lebih lama daripada A. Dengan demikian, hanya seorang ahli waris atau legataris yang ada yakni A atau B, siapa di antara mereka yang hidup lebih lama. Seakan-akan pada making dengan syarat membatalkan ada dua orang berturut-turut menikmati wasiat tersebut tetapi dalam kenyataannya hanya seorang ahli waris saja yang ditunjuk dalam wasiat tersebut.

Pengangkatan waris (making) bersyarat (membatalkan) tidak bertentangan dengan undang-undang mengingat adanya ketentuan berlaku surut pada syarat membatalkan, sedangkan yang dilarang adalah pengangkatan waris atau pemberian hibah wasiat dengan lompat tangan (pasal 879, ayat 2, KUHPerdata). ${ }^{22}$

Wasiat dengan syarat batal apabila dibandingkan dengan pengangkatan waris dengan lompat tangan (fideï-commis) tidak ditemukan ciri khas utama fideïcommis, yakni periode dari pemikul beban (den bezwaarden persoon) dan periode bagi ahli waris yang menunggu (de verwachters) untuk menjadi pemilik atas harta warisan atau harta hibah wasiat. Melihat posisi ahli waris yang menunggu pada fideï-commis tersebut, maka pada kasus wasiat dengan syarat batal pada kenyataannya hanya seorang saja menjadi pemilik setelah dipenuhi syarat yang ditentukan oleh pewaris, apakah A atau B yang hidup lebih lama.

Ahli waris yang menunggu (de verwachter) digambarkan sebagai ahli waris atau legataris dengan syarat membatalkan yakni menunggu siapa yang hidup lebih lama. Maksud dari pewaris dapat dicapai melalui making bersyarat daripada melalui pengangkatan waris dengan lompat tangan fideï-commis.

Suatu tindakan hukum dapat dilakukan dengan memakai beban (last), termasuk pemberian beban (last) pada pengangkatan waris (making) atau hibah

22 Pasal 879, ayat 2, KUHPerdata: "Oleh karena itu, pun bagi si yang diangkat atau yang menerima hibah, batal dan tak berhargalah setiap ketetapan, dengan mana masing-masing mereka diwajibkan menyimpan barang-barang warisan atau hibahnya, untuk kemudian menyerahkannya, baik seluruhnya maupun untuk sebagian, kepada orang ketiga”. 
wasiat (legaat) di dalam suatu wasiat. Pada ketentuan bersyarat, dengan terjadinya peristiwa yang belum pasti telah dipenuhi syarat dan berakibat hukum. Pada tindakan hukum dengan beban (last) periode ketidakpastian secara de facto ada; periode tersebut akan berakhir bukan karena diakhirinya ketidakpastian tetapi keharusan dilaksanakannya beban (last) oleh penerima beban (lasthebber) yang merupakan kepentingan dari pihak penentu beban (lastgever). Konstruksi tindakan hukum atas beban (last) sejak semula mempunyai akibat hukum. Dengan tidak dipenuhinya beban (last) tersebut pada kenyataannya memang membawa efek yang sama dengan syarat membatalkan, sebagaimana bunyi ketentuan pasal 1004, ayat 1, KUHPerdata:

"Pernyataan gugurnya suatu wasiat, boleh dituntut setelah meninggalnya si yang mewariskan, karena tak dilaksanakannya syarat-syarat yang ditetapkan di dalamnya. (...) " dan

Pasal 1688, angka 1, KUHPerdata:

"Suatu hibah tidak dapat ditarik kembali maupun dihapuskan karenanya, melainkan dalam hal-hal yang berikut:

1) karena tidak dipenuhi syarat-syarat dengan mana penghibahan telah dilakukan; (...)".

Setelah ada kepastian bahwa syarat berupa beban (last) telah dilaksanakan, maka keuntungan dapat dinikmati dan untuk keperluan tersebut tidak diperlukan pernyataan apapun. Di lain pihak apabila syarat berupa beban (last) tidak dipenuhi, maka barang-barang yang berada di tangan ahli waris atau legataris (penerima hibah) diambil kembali (pasal 1004, ayat 2, KUHPerdata dan pasal 1689, ayat 1 , KUHPerdata).

Pada making bersyarat tidak ada kewajiban memenuhi syarat tersebut sedangkan pada making dengan beban (last) penerima beban harus melaksanakan kewajiban (beban) untuk mendapatkan keuntungan yang dijanjikan pewaris. ${ }^{23}$

Tujuan pewaris pada pengangkatan waris (making) atau hibah wasiat (legaat) atas beban adalah agar orang yang ditunjuk mendapat keuntungan wajib

${ }^{23}$ Supra no 5, hlm., 36. 
melakukan tugas yang dibebankan kepadanya. Keuntungan dan kewajiban jatuh bersamaan kepada ahli waris berdasarkan pengangkatan waris (making) atau hibah wasiat (legaat) tersebut dalam artian bahwa apabila kewajiban tidak dilaksanakan, maka keuntungan tidak akan diperoleh.

Syarat Yang Tidak Mungkin (Onmogelijke Voorwaarde), Syarat Yang Perlu (Noodzakelijk Voorwaarde), Syarat Bertentangan Dengan Undang-Undang (Onwettige Voorwaarde), Syarat Bertentangan Dengan Kesusilaan (Onzedelijke Voorwaarde), Syarat Potestatif, Dan Syarat Yang Tidak Dimengerti (Onverstaanbare Voorwaarde) ${ }^{24}$

Berdasar pada ketentuan umum demikian pula melalui doktrin, yurisprudensi, dan literatur dikenal pula syarat yang tidak mungkin, syarat yang tidak dimengerti dan berkembang menjadi beberapa penamaan dan perbedaan di dalam praktik. Perkembangan yang terjadi adalah dikenalnya syarat yang tidak mungkin (onmogelijke voorwaarde), syarat yang perlu (noodzakelijk voorwaarde), syarat yang bertentangan dengan kesusilaan (onzedelijke voorwaarde), syarat yang bertentangan dengan undang-undang (onwettige voorwaarde), syarat potestatif dan syarat yang tidak dimengerti. (onverstaanbare voorwaarde).

Pada hakekatnya semua jenis syarat yang disebutkan tersebut bermuara dan berdasar pada ketentuan umum mengenai syarat menangguhkan dan syarat membatalkan dengan perbedaan sumier.

"Syarat yang bertujuan tidak melakukan sesuatu yang tak mungkin terlaksana, tidak membuat perikatan yang digantungkan padanya, tak berdaya", bunyi pasal 1255, KUHPerdata. "Apabila anjing saya dapat menghabiskan air laut", adalah sebenarnya bukan syarat karena tidak mungkin terjadi sehingga akan dianggap sebagai perikatan tidak bersyarat. Selain itu syarat yang tidak mungkin dilaksanakan adalah batal (pasal 1254, KUHPerdata).

Apabila para pihak di dalam syaratnya menyebutkan fakta yang ternyata telah terjadi atau tidak mungkin akan terjadi, maka dikatakan di sini telah

24 Id., hlm., 41. 
dijanjikan suatu syarat atau perikatan dengan syarat yang tidak mungkin dilaksanakan (pasal 1263, KUHPerdata). Ketidaktahuan para pihak akan fakta yang belum tentu tidak berarti ketidakpastian yang akan terjadi. Ada kadangnya ketidakpastian tersebut harus ditemukan (sendiri) oleh para pihak, misalnya syarat apabila telah adanya berita tentang terjualnya lukisan Affandi bertema tertentu telah mencapai harga tertentu. Kebenaran hal tersebut harus dicari kepastiannya oleh yang bersangkutan sendiri. ${ }^{25}$ Pada perikatan bersyarat peran para pihak selalu sangat menentukan. Pasal 1263, KUHPerdata seakan ingin mengatakan bahwa perikatan bersyarat adalah perikatan yang tanpa ketentuan ini akan dilihat sebagai perikatan tidak bersyarat. ${ }^{26}$

Syarat yang perlu (noodzakelijk voorwaarde) merupakan syarat dengan adanya unsur atau elemen "syarat" sebagai keharusan dan bukan ketidakpastian sehingga dalam hal ini pemenuhan syarat sudah pasti. Oleh karena itu dikatakan bahwa syarat yang mengharuskan sebenarnya tidak mengandung unsur syarat .27

Syarat yang bertentangan dengan undang-undang, misalnya A akan membayar sejumlah uang kepada B apabila B berhasil menyelundupkan sejumlah rokok merk tertentu ke tempat tertentu atau akan diberikan sejumlah uang apabila besok berhasil memukul kepala seseorang. Demikian pula diperjanjikan syarat yang berkaitan dengan warisan yang belum terbuka sebagaimana dilarang ketentuan pasal 1334, KUHPerdata, misalnya perjanjian antara A dan B dengan mensyaratkan bahwa A akan mengangkat B sebagai ahli waris dan B akan mengangkat pula A sebagai ahli waris.

Syarat yang bertentangan dengan kesusilaan biasanya berkaitan dengan kebebasan pribadi yang asasi, misalnya penghibahan dengan syarat apabila seseorang pindah agama tertentu. Semua syarat yang bertentangan dengan

25 Pendapat Asser-Rutten dan Hofmann-Van Opstall sebagaimana dikutip J.D.A. den Tonkelaar, Opschortende en ontbindende voorwaarden volgens BW en NBW, Tjeenk Willink, Zwolle, 1983, hlm., 44

${ }^{26}$ Id., hlm., 43.

${ }^{27}$ Id., hlm., 42. 
undang-undang dan kesusilaan baik adalah batal, demikian pasal 1254, KUHPerdata.

Syarat potestatif merupakan syarat yang pemenuhan syaratnya sebagian atau seluruhnya tergantung pada kehendak salah satu pihak (pasal 1256, ayat 1, KUHPerdata), misalnya A akan menghibahkan kepada B apabila A sudah berkeinginan untuk melakukannya.

Apabila untuk pemenuhan atau tidak dipenuhinya syarat yang bukan semata-mata tergantung pada satu pihak saja, maka syarat tersebut tidak digolongkan pada syarat potestatif yang dilarang undang-undang.

Kapan suatu syarat potestatif diperbolehkan dan kapan tidak diperbolehkan akan diberikan beberapa contoh:

a. beding jual beli atas penilaian warna dari beberapa macam bentuk barang "didasarkan atas penilaian dari pembeli" atau "didasarkan atas penilaian dari pihak ketiga yang ditunjuk para pihak". Syarat semacam ini diperbolehkan karena untuk pemenuhan syarat tidak tergantung dari kemauan sendiri dari satu pihak (pembeli) tetapi mendasarkan pada penilaian dan ukuran tertentu yang obyektif.

b. Penjualan saham milik pemegang saham apabila disetujui oleh rapat umum pemegang. Syarat inipun diperbolehkan karena penentuan syarat ditentukan rapat pemegang saham yang berada di luar keinginan pemilik saham yang hendak menjual sahamnya.

c. beding pada jual beli di mana pihak pembeli bebas menentukan jadi atau tidaknya membeli tergantung apabila keadaan keuangan pembeli telah membaik. Syarat ini tidak diperbolehkan karena semata-mata tergantung pada keinginan pembeli (apabila keadaan keuangan pembeli membaik) untuk menentukan dilakukan atau tidaknya jual beli.

Di bidang hukum waris, dikenal "syarat yang tak dapat dimengerti, atau tak mungkin dilaksanakan atau yang bertentangan dengan kesusilaan baik" harus dianggap sebagai tak tertulis, misalnya syarat bahwa penerima hibah wasiat 
(legataris) tidak boleh menikah (pasal 888, KUHPerdata). Berarti, wasiat yang memuat syarat tersebut tetap sah tetapi syarat yang dimaksud dianggap tidak ada. Ada kalanya tergantung pula pada isi muatan syarat di dalam wasiat yang dapat mengakibatkan wasiat/hibah wasiat (legaat) seluruhnya menjadi batal apabila alasan mengapa pewaris di dalam mengangkat ahli waris atau memberikan hibah wasiat ternyata didasarkan pada kepalsuan alas sebab (pasal 890 dan pasal 891 KUHPerdata).

Ketentuan mengenai syarat (membatalkan) yang dimuat dalam hibah wasiat (legaat) harus hati-hati di dalam mencantumkannya mengingat adanya larangan pengangkatan waris dengan lompat tangan (fidei-commis). Tanpa sadar pembuat wasiat bermaksud untuk tetap terus mengatur harta peninggalannya. Suatu wasiat akan gugur dan dapat dinyatakan gugurnya suatu wasiat setelah meninggalnya pewaris, karena tak dilaksanakannya syarat yang ditetapkan di dalamnya (pasal 1004, ayat 1, KUHPerdata).

Syarat yang tidak dimengerti (onverstaanbare voorwaarde) apabila syarat tersebut tidak dapat diselidiki apa yang diinginkan/dimaksudkan atau syarat yang kompleks. Di dalam wasiat yang syaratnya tidak dimengerti harus dianggap tidak tertulis (Pasal 888 KUHPerdata). Pada umumnya syarat yang tidak dimengerti adalah sama dengan tidak berarti sehingga digolongkan sama dengan syarat yang tidak dapat dilaksanakan dan dalam hal demikian diterapkan ketentuan Pasal 888 KUHPerdata mengenai wasiat yang syaratnya tidak dimengerti sehingga perikatannya berakibat batal. ${ }^{28}$

\section{Syarat Batal Dan Janji Menanggung Atau Menjamin (Garansi)}

Ketentuan Pasal 1316 KUHPerdata memperbolehkan ditutupnya perjanjian untuk menanggung atau menjamin seorang pihak ketiga ${ }^{29}$ yang dikenal sebagai perjanjian garansi (garantie-overeenkomst). Perjanjian garansi berbeda dengan

\footnotetext{
${ }^{28}$ Id., hlm. 60.

29 Teks asli: “(...) voor eenen derde sterk maken of instaan door te beloven (...) yang artinya adalah menguatkan atau menjamin pihak ketiga dengan berjanji (...)".
} 
perjanjian penanggungan utang (borgtocht) yang diatur di dalam Buku Ketiga, Bab ketujuh belas (Pasal 1820-1850 KUHPerdata). Jaminan atau beding garansi adalah suatu janji untuk menanggung atau menjamin seseorang bahwa pemberi garansi akan berbuat sesuatu dengan tidak mengurangi tuntutan pembayaran ganti rugi terhadap siapa pemberi garansi telah menanggung atau menguatkan sesuatu, jika pihak yang dijamin atau diberi garansi menolak memenuhi perikatannya (Pasal 1316 KUHPerdata). ${ }^{30}$

Kadang sulit untuk membedakan antara perjanjian garansi dengan perikatan dengan syarat membatalkan. Misalnya. A menjual kepada B sebuah café di mana A secara lisan menjamin B bahwa izin usaha café tersebut pasti diperoleh dan akan tertulis atas nama B. B kemudian menanyakan kepada A apakah diperolehnya izin usaha café atas nama B merupakan syarat dan apakah tidak sebaiknya dimuat di dalam perjanjian jual beli café antara A dan B. Hal tersebut dijawab oleh A bahwa ia menjamin bahwa apabila izin usaha tidak diperoleh maka A akan membayar sejumlah uang kepada B. Mendasarkan pada ketentuan Pasal 1258 KUHPerdata, pengadilan Alkmaar berpendapat bahwa tidak diperolehnya izin usaha café atas nama B bukan merupakan sekadar janji menjamin (garansi) tapi lebih sebagai syarat membatalkan. ${ }^{31}$

\section{Syarat Batal Pada Perjanjian Timbal Balik ${ }^{32}$}

Syarat batal pada perjanjian timbal balik yang diatur di dalam ketentuan pasal 1266 dan pasal 1267 KUHPerdata sebagaimana halnya dengan perikatan bersyarat seharusnya dimuat di Bagian Umum dari perjanjian dan bukan di Bagian Kelima tentang "Perikatan-Perikatan Bersyarat"

Wanprestasi dikaitkan dengan syarat batal pada perjanjian timbal balik (pasal 1266 KUHPerdata) dan memberikan kepastian (hukum) untuk batalnya perjanjian timbal balik manakala salah satu pihak tidak memenuhi kewajibannya.

\footnotetext{
30 Supra no 1, hlm., 156-158.

31 Supra no 5, hlm., 2.

32 Supra no 1, hlm., 225-242..
} 
Undang-undang menganggap wanprestasi sebagai syarat batal sebagaimana dimaksudkan pasal 1265, ayat 1, KUHPerdata dan membawa segala sesuatu kembali pada keadaan semula, seolah-olah tidak pernah ada suatu perikatan. Untuk batalnya perikatan tersebut harus dimintakan putusan hakim menurut ayat 2, pasal 1266 KUHPerdata.

Hoge Raad telah berkali-kali memutuskan bahwa putusan hakim adalah memastikan bahwa telah terjadi wanprestasi dan perikatan batal sejak wanprestasi terjadi bukan sejak putusan pengadilan. Konklusi yang diambil adalah, bukan putusan hakim tetapi wanprestasi yang menjadi dasar batalnya perjanjian.

Oleh karena itu praktis sejak wanprestasi "tertua" yang dianggap merupakan dasar berakhirnya perjanjian apabila ada beberapa perjanjian saling berkaitan dan beberapa wanprestasi telah terjadi di antara perjanjian-perjanjian tersebut.

Undang-undang memungkinkan salah satu pihak pada perjanjian timbal balik 33 yang sudah tidak mendapatkan prestasi yang diperjanjikan untuk minta pembatalan dan dibebaskan dari kewajiban untuk melakukan prestasi.

Ketentuan pasal 1265, ayat 1, KUHPerdata yang menyatakan, bahwa suatu syarat batal adalah syarat apabila dipenuhi, menghentikan perikatan dan membawa segala sesuatu kembali, pada keadaan semula seolah-olah tidak pernah ada suatu perikatan. Wanprestasi yang dilakukan oleh salah satu pihak merupakan pemenuhan syarat batal pada perjanjian bersyarat yang selalu dianggap dicantumkan pada perjanjian timbal balik. Pasal 1265 KUHPerdata bukan merupakan perikatan dengan ketetapan waktu (tijdsbepaling) dan tidak menangguhkan pemenuhan perikatan; ketentuan ini hanya mewajibkan debitur untuk mengembalikan apa yang telah diterimanya apabila peristiwa yang dimaksudkan terjadi.

33 Supra no. 1, hlm., 54. 
Dasar dari syarat batal adalah kepatutan karena justru pada perjanjian timbal balik adanya prestasi yang satu dikaitkan dengan prestasi dari pihak lawan, sehingga dalam hal tidak dipenuhinya prestasi oleh salah satu pihak menimbulkan hak pada pihak lawan untuk minta agar perjanjian dibatalkan.

Pasal 1265, ayat 2, 3, dan 4, KUHPerdata menyebutkan bahwa pembatalan harus dimintakan kepada hakim. Hogeraad ${ }^{34}$ telah lama berpendapat, bahwa ketentuan Pasal 1302 dan 1303 (BW oud) (sama dengan pasal 1266 dan 1267 KUHPerdata) bukan merupakan ketentuan yang bersifat ketentuan umum (van openbare orde) sehingga para pihak dapat mengesampingkan berlakunya pasalpasal tersebut. ${ }^{35}$ Artinya, apabila para pihak dengan tegas telah menyatakan melepaskan ketentuan Pasal 1266 dan 1267 KUHPerdata, maka dalam hal adanya wanprestasi, perjanjian menjadi batal demi hukum tanpa adanya perantaraan/putusan hakim. ${ }^{36}$

Hofmann-Abbas berpendapat bahwa memang para pihak berwenang untuk menjanjikan batalnya perjanjian dengan tidak dipenuhinya prestasi oleh salah satu pihak, tanpa perantaraan hakim dan telah dengan tegas melepaskan Pasalpasal 1266 dan 1267 KUHPerdata karena ketentuan-ketentuan tersebut bukan merupakan ketentuan yang bersifat ketertiban umum. Namun demikian, perantaraan hakim masih diperlukan karena maksud melepaskan perantaraan hakim adalah hanya untuk memenuhi ketentuan ayat (3) Pasal 1266 KUHPerdata

3420 December 1850, W. 1203; 10 Januari 1862, W. 2343; 6 Maart 1872, W 3440; 2 December 1881, W. 4717; 7 Februari 1902, W. 7720; demikian pula diantaranya pendapat Van der Lek de Clercq, diss., hlm., 53; Asser-Van Goudoever, hal. 235; Suijling II I, no. 320, hlm., 508; Pitlo, hlm., 109, yang menurut mereka "om tussenkomst van de rechter uit te sluiten een werkelijke voorwaardelijke verbintenis zou moeten aangaan, hetgeen, zoals uit de teks blijkt, ongewenst is" (untuk mengeyampingkan perantaraan hakim merupakan keingingan (para pihak) adalah benar2 suatu perikatan bersyarat, sebagaimana bunyi teksnya), L.C. Hofmann, Bew. P. Abas, Het Nederlands verbintenissenrecht, Deel 1 tweede gedeelte, H.D.Tjeenk Willink, Groningen, 1977, hlm., 313-314.

35 C.Asser-L.E.H.Rutten II, Verbintenissenrecht, Algemene leer der overeenkomsten, vierde druk, W.E.J. Tjeenk Willink, Deventer, 1975, hlm., 311.

36 "In de praktijk wordt echter aangenomen, dat de partijen de rechterlijke macht tussenkomst kunnen uitschakelen door te bedingen, dat ingeval van wanprestatie de overeenkomst van rechtswege zal zijn ontbonden", C.Asser-L.E.H.Rutten II, Verbintenissenrecht, Algemene leer der overeenkomsten, vierde druk, W.E.J. Tjeenk Willink, Deventer, 1975, hal. 307. 
di mana hakim tidak perlu lagi menentukan terme de grâce, yakni waktu yang diberikan kepada debitur untuk masih dapat memenuhi prestasinya. Lebih baik diperjanjikan dalam perjanjian, bawah perjanjian akan batal bila salah satu pihak tidak memenuhi kewajibannya, dan pihak debitur telah mengakui terjadinya wanprestasi. ${ }^{37}$

Ketentuan khusus berkaitan dengan jual beli barang dagangan dan barang perabot rumah, yakni pembatalan pembelian untuk keperluan si penjual akan terjadi demi hukum dan tanpa peringatan, setelah lewatnya waktu yang ditentukan untuk mengambil barang yang dijual (Pasal 1518 KUHPerdata).

\section{Daftar Pustaka}

\section{Buku:}

Asser-Rutten, De verbintenis in het algemeen, deel I, Zwolle, 1981.

A Pitlo, bewerkt door Gr. van der Burght, Het Erfrecht, deel 5, Arnhem, 1977.

C.W. Opzomer, Het Burgerlijk Wetboek verklaard, vijde deel, Amsterdan, 1879.

G. Diephuis, Het Nederlandsch Burgerlijk regt, Groningen, 1886.

Herlien Budiono, Ajaran Umum Hukum Perjanjian dan Penerapannya di Bidang Kenotariatan, PT Citra Aditya Bakti, Bandung, 2014.

Jac. Hijma en M.M. Othof, Compendium van het Nederlands Vermogensrecht NBW, Tjeenk-Willink, Deventer, 1982.

J.D.A. den Tonkelaar, Opschortende en ontbindende voorwaarden volgens BW en NBW, Tjeenk Willink, Zwolle, 1983.

L.C. Hofmann-S.N. van Opstall, Het Nederlands verbintenissenrecht, deel 1, negende druk, Tjeenk-Willink, Groningen, 1976.

Susi Moeimam, Hein Steinhaur, Kamus bahasa Belanda-Indonesia, PT Gramedia Pustaka Utama, Jakarta, 2005.

\section{Peraturan perundang-undangan:}

Kitab Undang-Undang Hukum Perdata.

Nieuw Burgerlijk Wetboek (NBW)

37 Id., hlm., 312. 